\title{
Impact of IBA and NAA on Rooting and its Growth Parameters of Air Layers in Guava (Psidium guajava L.)
}

\author{
Bhuriya Verma ${ }^{1}$, Poonam Bhadauriya ${ }^{1}$, Usha Parmar ${ }^{1}$, \\ Raj Kumar Dhakad ${ }^{2 *}$ and K. S. Tomar ${ }^{1}$ \\ ${ }^{1}$ Deparment of Horticulture, fruit science, college of Agriculture Gwalior, Rajmata Vijayaraje \\ Scindia Krishi Vishwa Vidyalaya, Gwalior, Madhya Pradesh, India \\ ${ }^{2}$ Deparment of vegetable science, School of Agriculture and Rural Development, \\ BRAUSS Mhow, M.P, India \\ *Corresponding author
}

\section{A B S T R A C T}

\section{Keywords}

Callus, NAA, IBA,

Primary and secondary roots

\section{Article Info}

Accepted:

15 September 2019

Available Online:

10 October 2019
The present investigation entitled Impact of IBA and NAA on rooting and its growth parameters of air layers in guava. (Psidium guajava L.). The experiment was conducted at the Nursery area, Department of Horticulture, College of Agriculture, Rajmata Vijyaraje Scindia Krishi Vishwa Vidyalaya, Gwalior (M.P.) during the session 2016 - 2017. The experiment was laid out in Randomized Block Design with 16 treatment combinations consisting of three level of IBA, $\mathrm{I}_{0}=0$ ppm (Control), $\mathrm{I}_{1}=5,000 \mathrm{ppm}$ IBA, $\mathrm{I}_{2}=10,000 \mathrm{ppm}$ IBA, $\mathrm{I}_{3}=15,000 \mathrm{ppm}$ IBA and three level of NAA, $\mathrm{N}_{0}=\mathrm{o}$ ppm (Control), $\mathrm{N}_{1}=5,000$ ppm NAA, $\mathrm{N}_{2}=10,000$ ppm NAA, $\mathrm{N}_{3}=15,000 \mathrm{ppm}$ NAA. Maximum rooting and its growth parameters were found significantly superior under the treatment of $I_{3}(15,000 \mathrm{ppm}$ IBA) followed by treatment $I_{2}$ and $I_{1}$ and for NAA treatments, treatment $N_{3}=$ $15,000 \mathrm{ppm}$ NAA was observed significantly higher followed by $\mathrm{N}_{2}=10,000 \mathrm{ppm}$ NAA in all the parameters. Interaction of $\mathrm{I}_{3} \mathrm{~N}_{3}$ was also find out better than all the treatments, callus formation, number of primary roots/ air-layer, length of primary roots, diameter of primary roots, number of secondary roots / layer, length of secondary roots, diameter of secondary roots, fresh weight of roots/ air-layer, success in rooting percentage.

\section{Introduction}

Guava (Psidium guajava L.), is one of the most important and popular fruit crop cultivated in India due to its wider soil and climatic adaptability, pleasant aroma, reasonable price, high nutritious value and availability for a long period of time during the year. Its native is Tropical America (from Mexico to Peru). In India the total area under 
guava cultivation was approximately 255 Thousand Hectares with an estimated annual production of 4048 Lakh Tonnes (Anonymous, 2016). Its fruit is rich in vitamin-C $(80 \mathrm{mg}$ of vitamin $\mathrm{C}$ in $100 \mathrm{~g}$ of fruit), Crude fiber $(0.9-1.0 \mathrm{~g})$ protein $(0.1-0.5$ g), carbohydrates $(9.1-17 \mathrm{mg})$, minerals $(\mathrm{Ca}$, $\mathrm{P}, \mathrm{Fe}$ etc.) and pectin (Kamath et al., 2008). The guava plant comes up well even under the harsh conditions owing to its hardy nature.

However, the main constraint in the popularization of guava is the preponderance of seedling progeny as seedling plants do not perpetuate the exact characters of particular superior selection in comparison to the vegetatively propagated fruit trees. Guava can be successfully propagated asexually by cutting (Kuperberg 1953), layering (Manna et al., 2004), grafting (Singh et al., 2005) and budding (Kaundal et al., 1987).

Air layering is only best and commercial reliable method for guava mass multiplication has an advantage over budding and grafting because, being on its own root the suckering problem is minimized and for stem cutting it require specialized environment conditions such as mist propagation beds (Nelson 1954).

The success in air layering of guava is mainly depends upon mother plant, time of layering, rainfall, humidity, temperature, rooting media, growth media, plant growth regulators and care during removal of bark from shoots. Airlayering is practiced during the month of JuneJuly with good success rates due to the relatively low temperature $\left(23^{\circ} \mathrm{C}\right.$ to $\left.31^{\circ} \mathrm{C}\right)$, high relative humidity (80 to $90 \%$ ) and rainfall which provides the conducive environment for the root initiation (Ahmed, 1964).

Layers prepared during these months get an additional advantage of longer duration of a favorable season for establishing the layer in the soil after preparation. The percentage of establishment and survival of rooted layers is reported to be poor, mainly due to hormonal imbalance and non-availability of standardized rooting media (Singh, 2002). Air layering with the help of plant growth regulators and rooting media is reported to stimulate root primordial in the air layers (Tyagi and Patel, 2004).

\section{Materials and Methods}

The experiment entitled "Impact of IBA and NAA on rooting and its growth parameters of air layers in guava. (Psidium guajava L.)" was carried out, during Rabi season of 2017-18 at the horticulture nursery, College of Agriculture, Gwalior during the year 201617. Gwalior is located at $26^{\circ} 13^{\prime} \mathrm{N}$ latitude and $78^{\circ} 14^{\prime} \mathrm{E}$ longitude and 208 meters above mean sea level.

The climate of Gwalior is subtropical with hot and dry summers where maximum temperature exceeds $45^{\circ} \mathrm{C}$ in May and June.

The winters are cool and minimum temperature reaches as low as $2^{\circ} \mathrm{C}$ in December and January; occurrence of frost is expected from the last week of December to the first week of February.

Usually the monsoon arrives in the second fortnight of June and lasts till September. Occasionally light rains are expected during winter. The annual rainfall ranges between 650 to $751 \mathrm{~mm}$, most of which received from end of June to end of September. Drought is the common feature due to the scanty and uneven distribution of rainfall.

The total of $467 \mathrm{~mm}$ rainfall was received during the experimental period. In the present investigation ten healthy branches were selected under each treatment and replicated four times to form the Asymmetrical Factorial Randomized Block Design with16 treatments 
and 64 plants of guava of uniform vigour and size were selected and about 1 (1-2) years old healthy branches of pencil thickness were selected for air-layering. The length of branches was 45-60 $\mathrm{cm}$ and diameter $1 \mathrm{~cm}$ approximately, 30 air-layers under each treatment and 1920 under the whole experiment were operated. The growth regulators were prepared in talcum powder base. First of all IBA and NAA with 5,000 ppm strength was prepared. 0.5 gm of growth regulators was weighed on electrical balance and then dissolved in about $10.00 \mathrm{cc}$ absolute alcohol. This solution was then thoroughly mixed with $99.5 \mathrm{gm}$ of talcum powder, IBA and NAA with $10,000 \mathrm{ppm}$ strength was prepared. $1 \mathrm{gm}$ of growth regulators was weighed on electrical balance and then dissolved in about $10.00 \mathrm{cc}$ absolute alcohol.

This solution was thoroughly mixed with 99 gm of talcum powder and IBA and NAA with 15,000 PPM strength was prepared. 1.5 gm of growth regulators was weight on electrical balance and then dissolved in about $10.00 \mathrm{cc}$ absolute alcohol (Table 1).

The solution was then thoroughly mixed with $98.5 \mathrm{gm}$ of talcum powd0er. For all treatment same rooting media were used which were prepared with (1:1) Soil+Fym and white colour polythene wrapper was used at the time of operation. After 65 days from the date of air layering prepared, air-layers were detached by making a cut just below the lowest end of the ringed surface with sharp secateurs. The airlayers were brought under shade after detachment and their polythene covers were removed gently.

Care was taken to ensure that the roots were not injured at the time of removing polythene wrapper.

After this, rooted air-layers were planted in polythene bags containing mixture of soil + FYM + leaf mould (2:1:1).

\section{Results and Discussion}

The data pertaining to callusing and root characters were recorded and statistically analyzed. The results are presented in Table 2, and graphically depicted in Figure 1 clearly shows that different concentrations of IBA, NAA and their combinations had significant effect on callusing and root characters.

\section{Effect of NAA on callusing and Root character of guawa air layering}

The data pertaining to naphthalene acetic acid (NAA) the maximum or higher callus formation $(5.35 \mathrm{~mm})$, number of primary (9.25) and secondary roots (14.25), length of primary $(4.27 \mathrm{~cm})$ and secondary roots $(1.72)$, diameter of primary $(1.87 \mathrm{~mm})$ and secondary roots $(1.52 \mathrm{~mm})$, fresh weight of roots $(1.29 \mathrm{gm})$ per air-layer were significantly recorded with the treatment $\mathrm{N}_{3}(15,000 \mathrm{ppm}$ NAA) followed by $\mathrm{N}_{2}$ and $\mathrm{N}_{1}$ and it might be due to different and suitable concentration of NAA. The present results are closely related with the findings of Bhagat et al., Rajput and Senjaliya (2015)and Sinish et al., (2005) in citrus, and Singh et al., (2007), Maurya et al., (2012) and Rymbai et al., (2012) in guava.

\section{Effect of IBA on callusing and Root character of guava air layering}

In respect to indole 3-butyric acid (IBA), the maximum or higher callus formation $(5.22 \mathrm{~mm})$, number of primary (8.22)and secondary roots (12.56), length of primary $(4.59 \mathrm{~cm})$ and secondary roots $(1.47 \mathrm{~cm})$, diameter of primary $(1.85 \mathrm{~mm})$ and secondary roots $(1.45 \mathrm{~mm})$, fresh weight of roots $(1.24 \mathrm{gm})$ per air-layer were significantly recorded with the treatmentI ${ }_{3}$ (IBA 15,000 ppm). The present results are closely related with the findings Rathore (1982), Bhagat et al., (1999), Das and Prasad (2014) Manga at el., (2017). 
Table.1 Treatments combination and concentration

\begin{tabular}{|c|c|c|c|c|c|}
\hline \multicolumn{3}{|c|}{ Treatments Combination } & Concentration of IBA & Concentration of NAA \\
\hline$I_{\mathbf{0}} \mathbf{N}_{\mathbf{0}}$ & $\mathrm{I}_{0} \mathrm{~N}_{1}$ & $\mathrm{I}_{0} \mathrm{~N}_{2}$ & $\mathrm{I}_{0} \mathrm{~N}_{3}$ & $\mathrm{I}_{0}=$ control. & $\mathrm{N}_{0}=$ control. \\
\hline $\mathrm{I}_{\mathbf{1}} \mathbf{N}_{\mathbf{0}}$ & $\mathrm{I}_{1} \mathrm{~N}_{1}$ & $\mathrm{I}_{1} \mathrm{~N}_{2}$ & $\mathrm{I}_{1} \mathrm{~N}_{3}$ & $\mathrm{I}_{1}=$ IBA@ 5,000ppm. & $\mathrm{N}_{1}=$ NAA@ 5,000ppm. \\
\hline $\mathrm{I}_{\mathbf{2}} \mathbf{N}_{\mathbf{0}}$ & $\mathrm{I}_{2} \mathrm{~N}_{1}$ & $\mathrm{I}_{2} \mathrm{~N}_{2}$ & $\mathrm{I}_{2} \mathrm{~N}_{3}$ & $\mathrm{I}_{2}=$ IBA@ 10,000ppm. & $\mathrm{N}_{2}=$ NAA@ 10,000ppm. \\
\hline $\mathbf{I}_{\mathbf{3}} \mathbf{N}_{\mathbf{0}}$ & $\mathrm{I}_{3} \mathrm{~N}_{1}$ & $\mathrm{I}_{3} \mathrm{~N}_{2}$ & $\mathrm{I}_{3} \mathrm{~N}_{3}$ & $\mathrm{I}_{3}=$ IBA@15,000ppm. & $\mathrm{N}_{3}=$ NAA@ 15,000ppm. \\
\hline
\end{tabular}

Fig.1 Effect of different concentration of IBA, NAA and their combination on Callusing and Root character studies

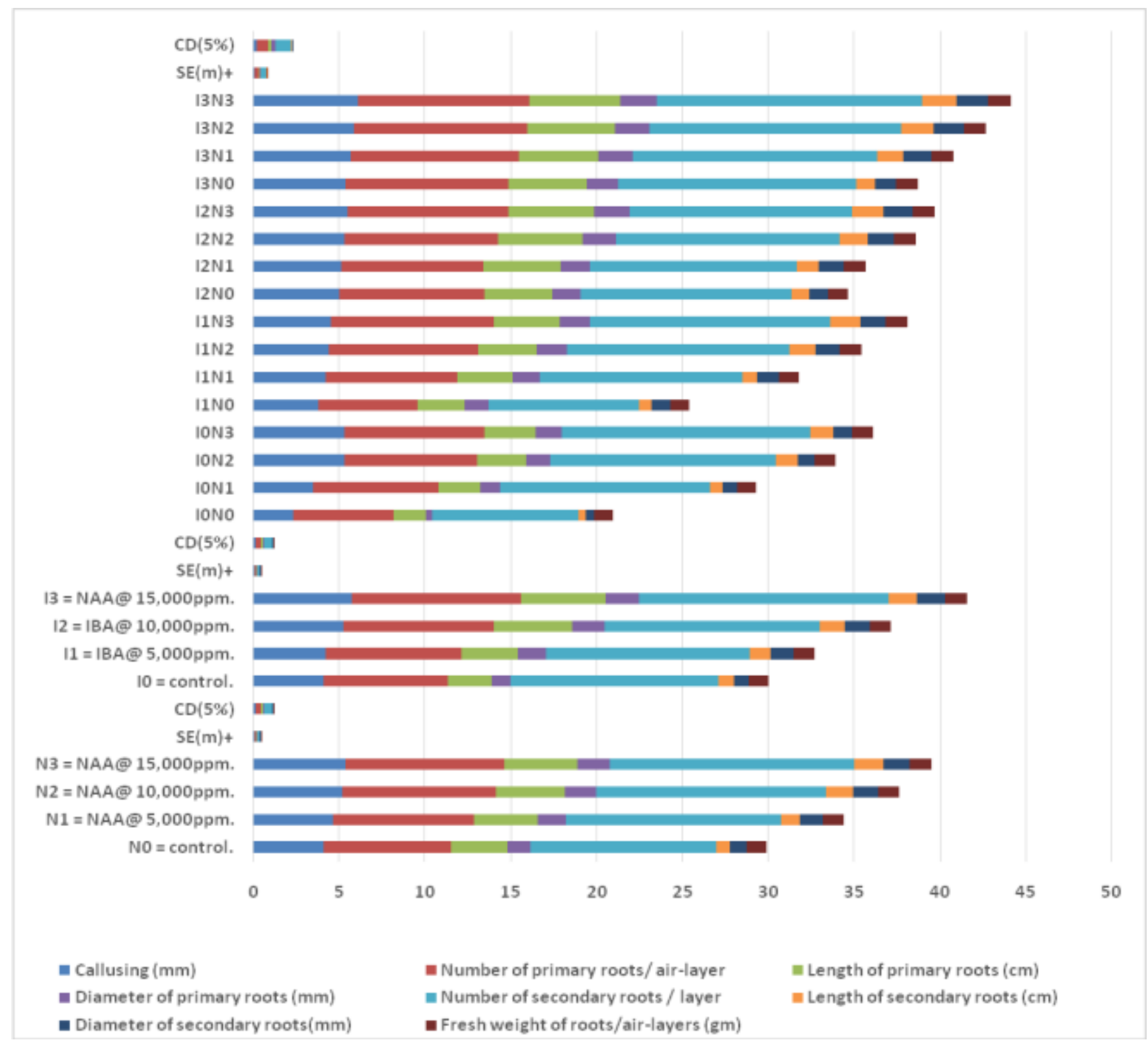


Table.2 Effect of different concentration of IBA, NAA and their combination on Callusing and Root character studies

\begin{tabular}{|c|c|c|c|c|c|c|c|c|}
\hline Treat. & $\begin{array}{c}\text { Callusin } \\
\mathbf{g}(\mathbf{m m})\end{array}$ & $\begin{array}{l}\text { Number } \\
\text { of } \\
\text { primary } \\
\text { roots/ air- } \\
\text { layer }\end{array}$ & $\begin{array}{l}\text { Length of } \\
\text { primary } \\
\text { roots } \\
\text { (cm) }\end{array}$ & $\begin{array}{c}\text { Diameter } \\
\text { of } \\
\text { primary } \\
\text { roots } \\
(\mathbf{m m})\end{array}$ & $\begin{array}{c}\begin{array}{c}\text { Number } \\
\text { of }\end{array} \\
\text { secondary } \\
\text { roots / } \\
\text { layer }\end{array}$ & $\begin{array}{l}\text { Length } \\
\text { of } \\
\text { seconda } \\
\text { ry roots } \\
(\mathrm{cm})\end{array}$ & $\begin{array}{c}\text { Diameter } \\
\text { of } \\
\text { secondary } \\
\text { roots } \\
(\mathbf{m m})\end{array}$ & $\begin{array}{c}\text { Fresh } \\
\text { weight of } \\
\text { roots/air- } \\
\text { layers } \\
\text { (gm) }\end{array}$ \\
\hline $\mathbf{N}_{0}=$ control. & 4.11 & 7.41 & 3.28 & 1.32 & 10.84 & 0.83 & 0.98 & 1.15 \\
\hline $\begin{array}{c}N_{1}=\text { NAA@ } @ \\
5,000 p p m .\end{array}$ & 4.62 & 8.23 & 3.72 & 1.62 & 12.58 & 1.11 & 1.31 & 1.19 \\
\hline $\begin{array}{l}N_{2}=\text { NAA@ } \\
10,000 p p m .\end{array}$ & 5.19 & 8.91 & 4.06 & 1.79 & 13.44 & 1.59 & 1.43 & 1.25 \\
\hline $\begin{array}{l}N_{3}=\text { NAA@ } @ \\
15,000 p p m .\end{array}$ & 5.35 & 9.25 & 4.27 & 1.87 & 14.25 & 1.72 & 1.52 & 1.29 \\
\hline $\mathrm{SE}(\mathrm{m}) \pm$ & 0.035 & 0.112 & 0.038 & 0.036 & 0.158 & 0.011 & 0.007 & 0.016 \\
\hline $\operatorname{CD}(5 \%)$ & 0.101 & 0.319 & 0.108 & 0.103 & 0.450 & 0.031 & 0.020 & 0.047 \\
\hline $\mathbf{I}_{0}=$ control. & 4.09 & 7.25 & 2.54 & 1.13 & 12.09 & 0.93 & 0.86 & 1.15 \\
\hline $\begin{array}{l}\mathbf{I}_{1}=\mathbf{I B A} @ \\
\mathbf{5 , 0 0 0 p p m} .\end{array}$ & 4.21 & 7.92 & 3.29 & 1.64 & 11.89 & 1.22 & 1.31 & 1.20 \\
\hline $\begin{array}{c}\mathbf{I}_{2}=\mathbf{I B A} @ \\
10,000 p p m .\end{array}$ & 5.22 & 8.78 & 4.59 & 1.85 & 12.56 & 1.47 & 1.45 & 1.24 \\
\hline $\begin{array}{l}I_{3}=\text { NAA@ } \\
15,000 p p m .\end{array}$ & 5.74 & 9.84 & 4.92 & 1.98 & 14.56 & 1.64 & 1.61 & 1.29 \\
\hline SE(m) \pm & 0.035 & 0.112 & 0.038 & 0.036 & 0.158 & 0.011 & 0.007 & 0.016 \\
\hline $\mathrm{CD}(5 \%)$ & 0.101 & 0.319 & 0.108 & 0.103 & 0.450 & 0.031 & 0.020 & 0.047 \\
\hline $\mathbf{I}_{0} \mathbf{N}_{\mathbf{0}}$ & 2.30 & 5.88 & 1.86 & 0.38 & 8.50 & 0.44 & 0.50 & 1.06 \\
\hline $\mathbf{I}_{\mathbf{0}} \mathbf{N}_{\mathbf{1}}$ & 3.50 & 7.25 & 2.47 & 1.16 & 12.25 & 0.69 & 0.85 & 1.11 \\
\hline $\mathbf{I}_{0} \mathbf{N}_{2}$ & 5.27 & 7.75 & 2.86 & 1.44 & 13.13 & 1.26 & 1.01 & 1.19 \\
\hline $\mathbf{I}_{\mathbf{0}} \mathbf{N}_{\mathbf{3}}$ & 5.32 & 8.13 & 2.98 & 1.56 & 14.50 & 1.33 & 1.09 & 1.23 \\
\hline $\mathbf{I}_{1} \mathbf{N}_{0}$ & 3.80 & 5.75 & 2.74 & 1.42 & 8.75 & 0.76 & 1.05 & 1.14 \\
\hline $\mathbf{I}_{1} \mathbf{N}_{1}$ & 4.19 & 7.68 & 3.21 & 1.61 & 11.80 & 0.85 & 1.29 & 1.16 \\
\hline $\mathbf{I}_{\mathbf{1}} \mathbf{N}_{\mathbf{2}}$ & 4.36 & 8.75 & 3.40 & 1.75 & 13.00 & 1.53 & 1.40 & 1.23 \\
\hline $\mathbf{I}_{\mathbf{1}} \mathbf{N}_{\mathbf{3}}$ & 4.50 & 9.50 & 3.82 & 1.79 & 14.00 & 1.75 & 1.51 & 1.26 \\
\hline $\mathbf{I}_{2} \mathbf{N}_{0}$ & 4.97 & 8.50 & 3.96 & 1.66 & 12.25 & 1.04 & 1.11 & 1.17 \\
\hline $\mathbf{I}_{2} \mathbf{N}_{1}$ & 5.13 & 8.25 & 4.55 & 1.71 & 12.00 & 1.33 & 1.45 & 1.24 \\
\hline $\mathbf{I}_{2} \mathbf{N}_{2}$ & 5.28 & 9.00 & 4.90 & 1.96 & 13.00 & 1.65 & 1.56 & 1.27 \\
\hline $\mathbf{I}_{2} \mathbf{N}_{3}$ & 5.51 & 9.38 & 4.94 & 2.07 & 13.00 & 1.84 & 1.67 & 1.30 \\
\hline $\mathbf{I}_{3} \mathbf{N}_{\mathbf{0}}$ & 5.36 & 9.50 & 4.58 & 1.83 & 13.88 & 1.08 & 1.25 & 1.23 \\
\hline $\mathbf{I}_{3} \mathbf{N}_{1}$ & 5.69 & 9.75 & 4.64 & 2.00 & 14.25 & 1.57 & 1.65 & 1.25 \\
\hline $\mathbf{I}_{3} \mathbf{N}_{2}$ & 5.85 & 10.13 & 5.10 & 2.02 & 14.63 & 1.94 & 1.73 & 1.32 \\
\hline $\mathbf{I}_{3} \mathbf{N}_{\mathbf{3}}$ & 6.06 & 10.00 & 5.34 & 2.09 & 15.50 & 1.97 & 1.84 & 1.35 \\
\hline $\mathrm{SE}(\mathbf{m}) \pm$ & 0.071 & 0.224 & 0.076 & 0.072 & 0.316 & 0.022 & 0.014 & 0.033 \\
\hline $\mathrm{CD}(5 \%)$ & 0.202 & 0.639 & 0.217 & 0.207 & 0.900 & 0.062 & 0.040 & NS \\
\hline
\end{tabular}


Interaction effect of NAA and IBA on callusing and Root character of guawa air layering

The interaction of IBA and NAA were also found significant which indicate that, the maximum callus formation, number of primary and secondary roots, length of primary and secondary roots, diameter of primary and secondary roots but the fresh weight of root war recorded non-significant.

It is concluded that NAA treatment $\mathrm{N}_{3}=$ $15,000 \mathrm{ppm}$ NAA,IBA treatment $\mathrm{N}=15,000$ ppm IBA and its interaction effect is best which significantly influenced the rooting and rooting growth character of guava.

\section{References}

Ahmed, R. (1964). Propagation of guava by aerial layering. W. Pakistan J.Agri. Res., 2: 62-74.

Anonymous (2016). National Horticulture Board, Indian Horticulture Database. Ministry of Agriculture, Govern-ment of India.

Bhagat, B. K., Jain, B. P., Singh, C. and Choudary, B. M. (1999), Studies on the propagation of guava (Psdium guajava L.) by ground layering in poly bags. Orissa J. Horticulture. 27(1):1921.

Chawla, W., Mehta, K. and Chauhan, Neena (2012). Influence of plant growth regulators on rooting of litchi (Litchi chinensis Sonn.) air layers, Asian J. Hort., 7(1): 160- 164.

Das, A.K. and Prasad, B. (2014). Effect of plant growth regulators on rooting survival of air layering in litchi. $A d v$. Res. J. Crop Improv. 5 (2): 126-130.

Das, Ajay Kumar and Prasad, Birendra (2014). Effect of plant growth regulators on rooting survival of air layering in litchi. Adv. Res. J. Crop Improv. 5 (2): 126-130.
Kamath J.V., Nair Rahul, Ashok Kumar C.K., Mohana Lak-shmi S. (2008). Psidium guajava L: A review, Interna-tional Journal of Green Pharmacy, 2 (1): 912.

Kaundal, G.S., Gill, S.S. and Minhas, P.P. (1987). Budding techniques in clonal propagation of guava. Punjab Hort. J., 27: 208-11.

Kuperberg, Joel. (1953). Rooting guava (Psidium guajava c. supreme) stem cutting in a hydroponic mist type plant propagator. Fla. State Hort. Soc. Proc.: 220-223: 1953.

Manna, A. Mathew, B. and Ghosh, S.N. (2004). Air layering in guava cultivars. Journal of Inter academicia. 2: 278281.

Maurya, R.K., Ray, N.R., Chavda, J.C., Chauhan, V.B. and Patil, A.K. (2012), Evaluation of different Organic media and water holding materials with IBA on rooting and survival of layering in guava (Psdium guajava L.) cv. Allahabad Safeda. Asian Journal of Horticulture. 7 (1): 44-47.

Nelson, R. O. (1954). Propagation of guavas by graftage. In Proc. Fla. State Hort. Soc (Vol. 67, p. 231).

Rajput R.P. and Senjaliya G.S. (2015) Effect of various plant growth regulators on yield And quality of guava (Psidium guajava L.) cv. Lucknow 49 International journal of agri. Science.11(1): 179-182

Rathore,T.R.(1982), Studies on the effect of different rooting media and various concentration of IBA on rooting, growth and survival of air-layering of guava. M.Sc. (Ag.) Thesis, J.N.K.V.V., College of Agriculture, Jabalpur (M.P.).

Rymbai, H., Sathyanarayana, Reddy G. and Reddy, K.C.S.(2012), Effect of cocopeat and sphagnum moss on guava air-layers and plantlets survival 
under open and polyhouse nursery. Agric. Sci. Digest, 32(3): 241-243.

Shrivastva, P.K. (2000). Effect growth regulators in combination and different rooting media on rooting and survival of air layers of guava (Psdium guajavaL.). var. G-27. unpublished thesis submitted to J.N.K.V.V. Jabalpur for the degree of MSc. (Ag).

Singh, Gorakh, Gupta, Soni, Mishra, Rajneesh and Singh, G.P. (2005). Wedge grafting in guava - A novel vegetative propagation technique, Pub. CISH, Lucknow, $12 \mathrm{p}$.

Singh, M. (2002). Response of plant growth regulators and wrappers on air-layering of guava (Psidium guajava L.). Advances in Plant Sciences, 15(1):153-157.

Singh, P., Chandrakar, J., Singh, A.K., Jain, V. and Agrawal, S.(2007), Effect on rooting in guava cv. Lucknow-49 through PGR and organic media under Chhattisgarh condition. Acta. Horticulture. 7(35):197-200.

Tyagi. S.K. and Patel. R.M. (2004). Growth regulators on rooting of air layering of guava (Psidium guajava L.) cv. Sardar. The Orissa Journal of Horticulture, 32(1): 58-62.

\section{How to cite this article:}

Bhuriya Verma, Poonam Bhadauriya, Usha Parmar, Raj Kuamr Dhakad and Tomar, K. S. 2019. "Impact of IBA and NAA on Rooting and its Growth Parameters of Air Layers in Guava (Psidium guajava L.)". Int.J.Curr.Microbiol.App.Sci. 8(10): 2041-2047.

doi: https://doi.org/10.20546/ijcmas.2019.810.237 